UDC 330.341.1:62.001.7; 338:004; 330.47; 338:002.5

DOI: https://doi.org/10.32782/2413-9971/2020-32-4

\author{
Zeynalov Anar \\ Ph.D. candidate, Department of "Economic Theory» \\ UNEC, Azerbaijan \\ ORCID: https://orcid.org/0000-0003-3111-4951
}

\title{
ROLE OF SCIENTIFIC AND TECHNICAL INNOVATIONS IN MODERNZATION ENVIRONMENT OF ECONOMY
}

Summary. The purpose of the research is to study the mechanisms of modernization of the economy and its impact on economic competition and development and to identify the contribution of innovative science and technology to the economic development of Azerbaijan. As a result of the research, the development prospects of innovative science and technology in our country and in the world have been analyzed, and the suggestions on the measures to be taken were made. The role of scientific and technical innovations in the modernization of the economy by analyzing foreign experience has been defined. The international experience on the development and application of new ideas, methods, products, etc. that will provide economic and social benefits in the direction of changing and updating their products, services, and production methods continuously based on the latest accomplishments of science and technology during economic activities of the states for demonstrating sustainability in a competitive environment that is strengthening among countries has been investigated and successful practices have been presented.

Key words: innovation, scientific and technological development, economic development, innovative development, technological changes.

Introduction. At all stages of the economy, development has always been associated with technologies; the success in science leads to technological development. For this reason, science, technology and development, as a whole, are in direct proportion to each other. In time, mankind has reached a point where science has become a technological product and mass production has begun. Currently, science, technology and innovation are considered the engine of sustainable economic development. In other words, science, technology, innovation and entrepreneurship are among the basic principles of modern economy. Innovation is the main basis of technological growth. Innovations also have a significant impact on achieving better living standards. The development degrees that the developing countries can emerge as centers of economic power depend on their ability to apply the concepts of science and technology. In the new era, modernization in the public life of any society is considered the most obvious example of the application of science and technology. Our lives have been simplified with the application of the latest achievements of science and technology. Science and technology permeated all spheres of economic (sometimes public) life: health, transport, mechanical engineering, information technology and others, and in many cases they are completely covered. In the era of free growth and sustainable change, many countries are shaping economic policies that stimulate development and create new jobs. Information and communication technologies (ICT) are one of the important opportunities not only for fast-growing industries, but also for innovation and development. The innovations in technology and information and communication technologies (ICT) represent the developing 
path of the world nations for stimulating economic development, improving the quality of education, and solving gender issues in society.

Aim. The main aim of the article to analyze the role of scientific, technical innovations in modernization environment of economy.

Discussion. In the context of the growing number of mobile subscribers ( 6.8 billion) to the number of global population and about $40 \%$ of the world's population is online, the competitiveness ability of economies depends on the opportunities and capabilities of using modern technologies. Here, ICT affects the economy on 5 factors:

- Direct job creation;

- Contribution to GDP growth;

- Emergence of new services and industries;

- Workforce transformation;

- Business updates;

Science, technology and innovation are among the essential factors of our time to determine the economic and political power of nations.

In the world, the telecommunications industry, along with its growing importance in terms of annual turnover and employment opportunities, is also a goal of creating an information society that is developing as a global trend and has a special significance at the European Union (EU) level. The rapid technological developments in the field of telecommunications since the 1990s, especially the digital revolution and the rapidly spreading Internet revolution around the world, have led to a rapid change in existing norms in the sector. This conceptual and theoretical revolution, driven by technology, is expected to advance further [1].

With scientific and technological development, the boundaries of human power have been transcended. This situation radically changed the production process. The production process was accelerated and the products were increased and sorted. These conditions naturally led to the reduction in unit production costs. After the Industrial Revolution, the changed world and economies were affected by these trends, and the race to participate in the New Economic Environment intensified.

The world economy is constantly changing in terms of competitive dynamics. In this process of transformation, many factors and strategies that affect countries and market participants in terms of competitiveness are also subject to transformation. This situation also directs the economic policy of the countries. In this transformation process, factors and strategies based on science, technology and innovation are key variables for global competition and social welfare. It is very important for market participants and countries to maintain a competitive advantage in a way that will make a difference between competitors in the context of global economic competition in order to improve their assets and well-being. Today the sources of competitive advantage depend on the strong integration of natural resources (reserves) to the given technologies (producing science, technology and innovation) [2].

Essence of Modernization of Science and Technology.

Today, if we pay attention to the fastest growing countries in the world, we will see the rapid development of science and technology along with economic development in those countries. Examples are Sweden, the Netherlands, and Germany. The only reason for the economic development of these countries is the investment in science and technological development. The results and scope of investment in this area are not limited to the economy. The development of science and technology is the only tool that influences all areas of society and is necessary to compete in all areas in our time. We can see evidence on the example of the countries that invest mostly in science and technology. These countries have a competitive advantage in the world in economic, military, educational and other spheres.

As can be seen from Figure 1, countries with high investment in research and development are also quite advanced in the economic, political, military, educational and other fields, and have a competitive advantage. As in many OECD (Organization for Economic Co-operation and Development) countries, the main strategy of research and development policy in Germany is to ensure a competitive advantage by increasing the innovative capacity of the industry. To this end, Germany pursues the following policies to maintain its competitive advantage by increasing its market share in international competition [3]:

1. to make structural adjustments and to act in accordance with market needs in order to make better use of its research and development potential;

2. efforts to increase research and development projects in small industries, support research and development by supporting technology parks and business incubators, individual firms, rewarding research staff, and increasing research and development staff.

The way of having strong economy and achieve social welfare is to own an industry and information sector that produces high-quality, world-class, high-value-added by-products with technologically superior features through the development of technology and innovation.

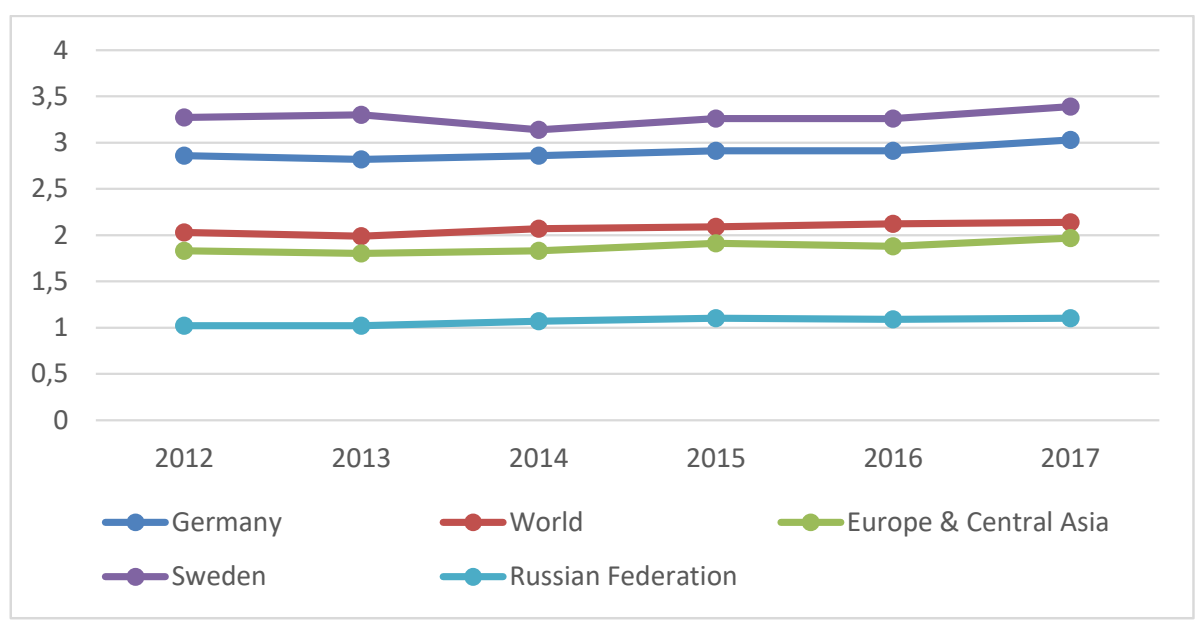

Figure 1. Research and development costs (GDP \%) [4] 


\section{Approximate GDP per capita}

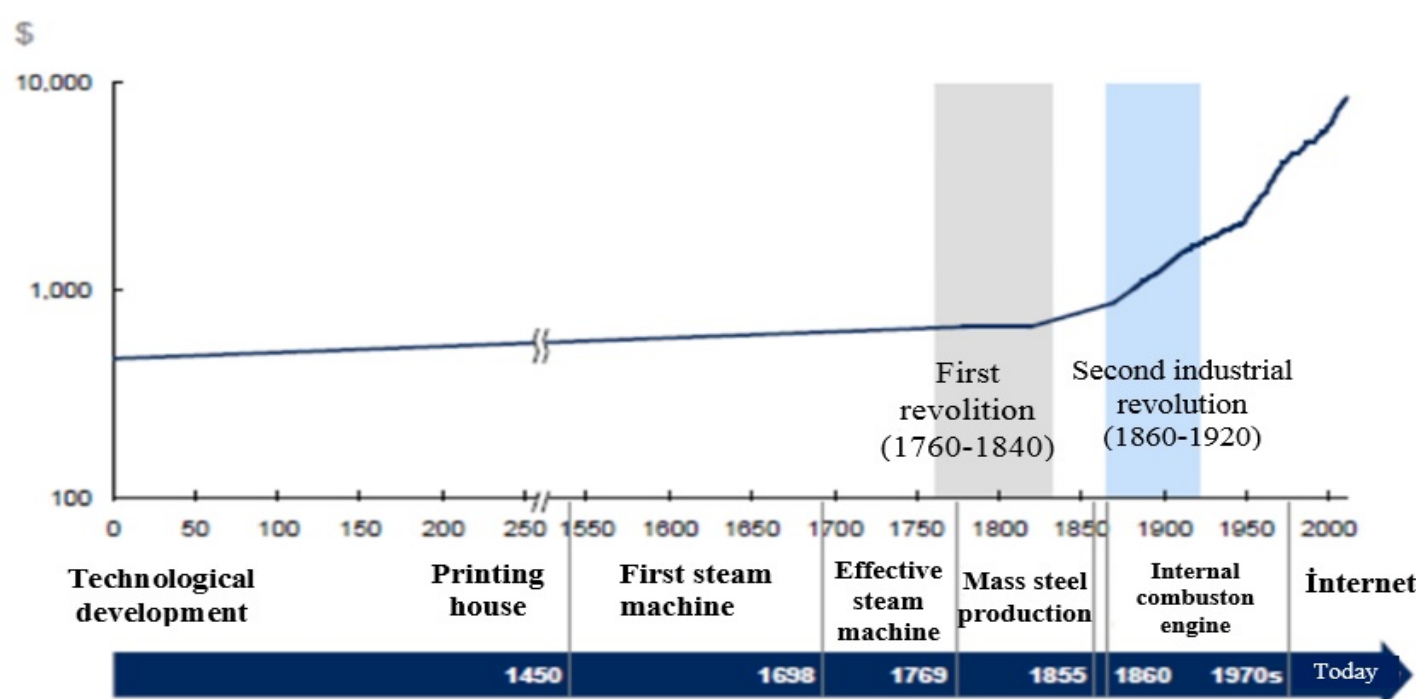

Figure 2. Economic impact of technological development [5]

The most important feature of our time is the ability of society to produce information. Each country carries out research and development activities to produce information in accordance with its potential. It is possible to acquire new products through research and development activities, and it is also possible to gain access to ready-made data or to teach how to use the obtained data. For this reason, all developed or developing countries attach great importance to research and development activities. The goal of the information society is to increase the impact of science and technology on economic and social development. As a result of obtaining and processing information, new technologies are produced. Although the produced technological information improves a person's standard of living, it becomes easier and faster for an individual to work alone (İsmail Hakk1 Yücel (1997), p. 27).

One of the main goals of economic modernization in many countries is to stimulate fundamental structural changes in the promotion of innovation, management of resources and environment in all areas, the widespread application of technology, and the application of important technologies aimed at improving the technological and technical base. Technological development is becoming one of the key factors of economic development and social welfare. In order to contribute to the modern technological regime, it is absolutely impossible to implement a successful structural innovation policy without large-scale involvement of the achievements of science and technology in trade.

The main global tendencies of innovation activities occurring at the end of the 20th century-beginning of the 21 st century are the followings:

- Increasing dependence of production of goods and services on the use of science and technology;

- Increasing number of new data producers;

- Dependence of innovation dynamics on successful interactions between scientific institutions and business sector;

- Development of interaction and cooperation of market participants;

- Diffusion of new technologies (currently, not with the purchase of new equipment, the changes in the organizational and management system are considered).

As a result of such trends, the analysis of structural changes in the economy are made on the basis of technological devel- opment, creates the need to study a large number of factors of innovation activity, focusing on interactions and information flows between participants in various innovation processes.

There has been three important revolutions in human history that affected economy. The first is the "Industrial Revolution", the second is the "Technological Revolution" occurred after the Second World War, and the third is the "Information Revolution" ("New Economy"). Since the start of the Industrial Revolution, unprecedented economic growth has taken place in the world economy. This can be seen in Figure 2:

When we look back historical processes, it seems clearly that the main source of evolution is technological development. Technological change altered the worldview, shaped people's lifestyles and increased their well-being.

The new technologies will create international competitive advantages. Technological innovations will help to increase competition and bring quality products to market. During this period, market participants will compete with each other to enter a larger market from a limited and complex market with the development of globalization. The information age is emerging as an evolving era of sustainable development, research and development, and the struggle for new information. This competition held for obtaining information will ensure sustainable development in societies.

The impact of developments in the dilemma of science, technology and innovation, global competitiveness at the macroeconomic level and socio-economic well-being will increase the effectiveness and success of policy designs in this area. At the microeconomic level, the main mechanism for increasing the competitiveness and profitability of scientific and technological innovation is to increase market share and increase profits by gaining competitive advantage through developments in scientific and technological innovation, reducing costs for companies, increasing productivity and expanding the range of products that differentiate competitors [2].

Mainly after the Second World War, innovations such as radar, nuclear energy, microwave, TV, radio, personal computers, mobile communications, and the Internet emerged as a result of rapid innovative activities and scientific research. This impulse, which started in the middle of the 19th century, has led to significant changes and developments today with the development of science and technology. At the same time, 
the ICT (information and communication technology) sector is the largest source of innovative activity, economic growth and employment. In the OECD (Organization for Economic Co-operation and Development) countries, the contribution of this sector to employment is $5.5 \%$, and the added value to working life is $8 \%$ [6].

The impact of developments in the dilemma of science, technology and innovation, global competitiveness at the macroeconomic level and socio-economic well-being will increase the effectiveness and success of policy designs in this area. At the microeconomic level, the main mechanism for increasing the competitiveness and profitability of scientific and technological innovation is to increase market share and profits by gaining competitive advantage through developments in scientific and technological innovation, reducing costs for companies, increasing productivity and expanding the range of products that differentiate competitors [2].

With the advent of the Internet and ICT products, lifestyles have undergone significant changes in recent years. Communicating with each other through networks has changed the way we communicate, and advances in information and communication technology have increased the level of well-being, innovation, and the number of new professions, as a result the information economy has been formalized.

\section{Success story}

In South Korea, the share of ICT in GDP increased from $7.7 \%$ in 1997 to $15.3 \%$ in 2000 . At the same time, the sector's contribution to GDP growth increased from $34 \%$ in 1999 to $46 \%$ in 2000. According to the World Bank, South Korea has become the fastest and most successful country to change its economic structure due to investments in the IT (Information Technology) sector [Kulali and Bilir, p.70]. With 129,000 employees in South Korea and more than 222,000 employees worldwide, Samsung operates in 58 countries and exports more than $\$ 150$ billion a year. In 2004, Samsung invested $\$ 4$ billion in China, a global hub for technological innovation. The investment generated \$ 24 billion in revenue in China the same year. Samsung is a product of South Korea's innovationbased development strategy dating back to the 1960s. It is no coincidence that Samsung has chosen China for investment. It is the result of China's innovation-based development strategy. South Korea, with its low inflation and unemployment rates, export surpluses, and income distribution, emerges as evidence of what innovation-based development and growth means.

\section{Development of Scientific and Technological Sphere in Azerbaijan}

Thanks to scientific and technological development, the world is undergoing great and rapid changes, and globalization plays a key role in accelerating this process. In parallel with the global economic development, new information and communication technologies are developing. Information and communication-based work lines are replacing traditional industries, and national incomes of ICT-invested countries are growing faster. As the most important factor of technical change and economic growth, it also brings significant structural changes in the telecommunications and IT sectors. Especially in the last 30 years, the development of computer and communication technologies has made innovation activity as a key factor in preventing global change.

Recently, several important activities in the direction of the development of science and technology have been carried out in our country. The most obvious example of this is the establishment of the "Science Development Fund under the President of the Republic of Azerbaijan" by the decree of President Ilham Aliyev dated October 21, 2009. At the same time, the "Strategic Road Map on the Development of Telecommunications and Information Technologies in the Republic of Azerbaijan" was developed with the goal to approve the "Main directions of the strategic roadmap on the national economy and key sectors of the economy" and to ensure the implementation of the tasks set by the President Ilham Aliyev's Order No. 1897 dated March 16, 2016. The goals of establishing the fund are to ensure scientific and technological development in the country and protect the existing potential in this direction, use this field effectively in economic development, increase the role of science and technology in solving important socio-economic problems, fund the fundamental, applied and research-innovative scientific researches, programs, projects and other scientific events important for the state and society in the field of technical, natural, humanities and social sciences provided by the education institutions, organizations, physical entities and other relevant bodies operating in the field of science in Azerbaijan, stimulate scientific activity of scientists and provide additional creative opportunity for them [7].

Azerbaijan's development in the field of science and technology depends on its ability to turn science and technology into economic and social benefits and its success in formalization of the National Innovation System. The use of technology parks is applied in many developed countries in terms of small and medium-sized industries. The joint cooperation of industry and universities aims to increase efficiency, quality and standards to the international level by adapting technological information to the industry as a result of research and development activities of the industry, in addition to increasing research and development activities in universities. For this reason, very serious work is being implemented in Azerbaijan in this direction. Examples of the work done are the establishment of Sumgayit Technopark and Sumgayit Chemical Industrial Park. In this regard, President Ilham Aliyev called Sumgayit Technopark an indicator of the country's growing economic power. The main purpose of creating technology parks is the development of the non-oil sector, the formation of an innovation-oriented economy and the promotion of innovative market participants. According to the 2019 Global Innovation Index (GII), Azerbaijan ranks 101st place in terms of science and technology. If we pay attention to the data in the index, it is possible to observe the growth rate over the years. The main dynamics of this growth rate is the policy of forming a science and technology-oriented economy in the country.

\begin{tabular}{|l|c|c|}
\hline & $\begin{array}{r}\text { Price/ } \\
\text { Value }\end{array}$ & $\begin{array}{c}\text { Rating } \\
\text { (129 countries) }\end{array}$ \\
\hline $\begin{array}{l}\text { 1. RESULTS OF KNOWLEDGE } \\
\text { AND TECHNOLOGY. }\end{array}$ & 14.9 & 101 \\
\hline 1.1 To create knowledge & 3.9 & 109 \\
\hline 1.2 Influence of knowledge & 21.4 & 111 \\
\hline 1.3 Spread of knowledge & 19.4 & 51 \\
\hline
\end{tabular}

Figure 3. Results of Knowledge and Technology in Azerbaijan in 2019 [8]

A characteristic feature of the innovation-oriented economy in the context of modernization of the economy is to stimulate the production of competitive products by ensuring long-term sustainable economic development, accelerating the application of science-based technologies, forming a knowledge economy, supporting innovative activities. The essence of modernization in Azerbaijan is more clearly reflected in the words of the President Ilham Aliyev: "The main task set for our country is to further develop the economy, carry out polit- 


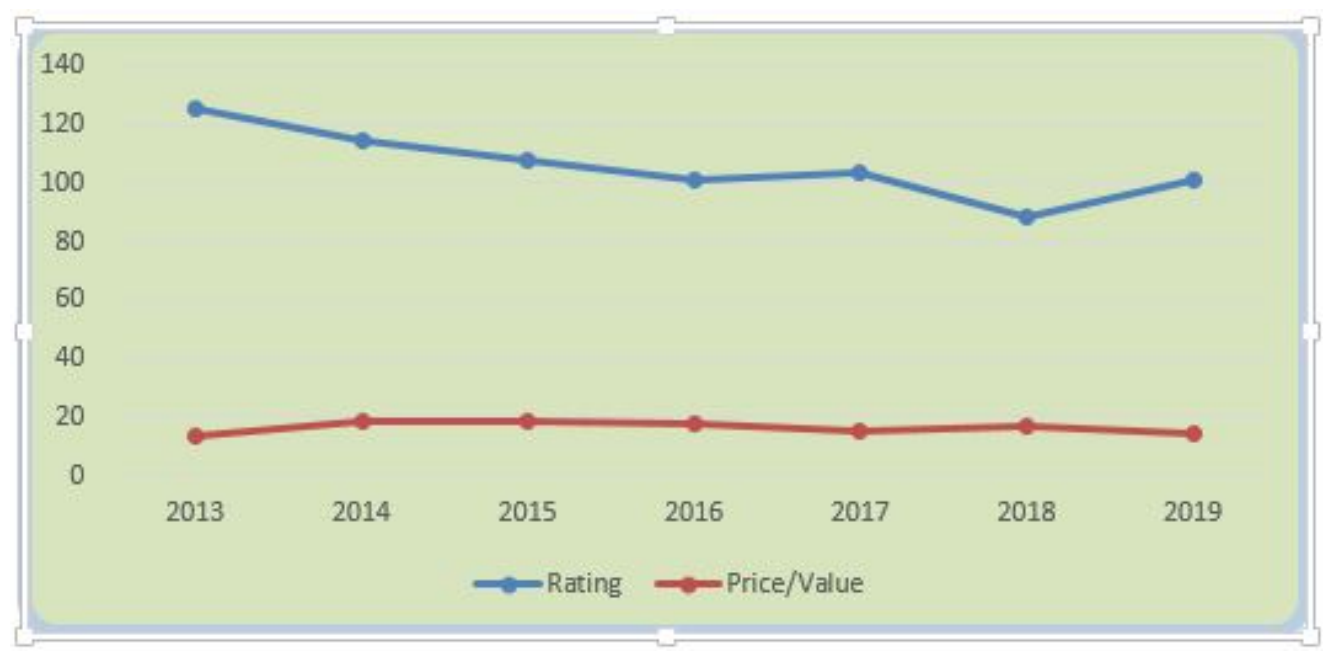

Figure 4. Results of Science and Technology in Azerbaijan in 2013-2019 [8]

ical reforms, modernization of the country. Much work has been done in this direction in recent years. We pursue a broad modernization policy in our country. This policy will allow us to become less dependent on energy resources".

Conclusions. Science and technology are the main drivers of development because technological and scientific revolutions ensure economic development, improvement of health, education and infrastructure. To promote scientific and technological progress, developing countries must invest in quality education for young people, provide continuous skills education for employees and managers, and ensure that information is disseminated as widely as possible in society. In the field of science and technology, it is important to establish and realize policies that will be implemented effectively, to bring the level of development to the desired level, so that the production and use of information and technology can be done with a certain system and coordination. Science and technology are one of the most important elements of long-term economic and social development. Science and technology policy is a tool to influence the pace and direction of this development. All eco- nomically and socially developed countries in the world (the USA, Japan, the EU member states) have developed a vision of science and technology that meets their long-term social, economic and political goals, and use technology forecasts as an effective tool to update this vision. In recent years, science and technology have played an important role in determining the level of development and classification of countries, and their importance is growing. There is a positive link between technology and growth and development, and there is a need to invest in technology in all countries targeting growth and development. If there is a need for technological investment, human capital must be high enough, that is, it depends on human resources that can use technology and develop new ones.

At the same time, the information society and literate generations will be provided by improving the education system and increasing the level of knowledge in society by allocating more funds to education. Societies that cannot turn scientific thought into a way of life will not be able to create an information society. The highly educated workforce trained in the country will determine the future of this country.

\section{References:}

1. Tulu Gümüştekin (2009) Bilgi Toplumu'nun lokomotifi olarak telekomünikasyon [Telecommunications as the locomotive of the Information Society], p. 1.

2. Rona Turanlı ve Ercan Sarıdoğan (2010) Bilim-Teknoloji-İnovasyon Temelli Ekonomi ve Toplum [Science-Technology-Innovation-Based Economy and Society]. İstanbul: Akademik Yayınlar, p. 7.

3. İsmail Hakkı Yücel (1997) Bilim-Teknoloji Politikaları ve 21. Yüzyılın Toplumu [Science-Technology Policies and the Society of the 21 st Century], p. 59 .

4. The World Bank (Annual). Available at: https://data.worldbank.org/indicator/GB.XPD.RSDV.GD.ZS (accessed 05 September 2020).

5. İsmail Hakkı Yücel (1997). Bilim-Teknoloji Politikaları ve 21. Yüzyılın Toplumu [Science-Technology Policies and the Society of the 21st Century], p. 27.

6. UNITED NATIONS ECONOMIC AND SOCIAL COMMISSION FOR ASIA AND THE PACIFIC (2018) p. 1. Angus Maddison,

7. "Statistic on world population, GDP and per capita GDP. 1-2000 AD". The Maddison Project database; McKinsey Global İnstute analysis. Available at: https://www.unescap.org/sites/default/files/MPFD\%20Policy\%20Brief\%2063\%20Technology_Final.pdf (accessed 05 September 2020).

8. İhsan Kulalı ve Hakan Bilir (2010) Bilgi ve İletişim Sektöründeki Gelişmeler ve Eğitimler [Developments and Trainings in the Information and Communication Sector]. TOBB, İstanbul, p. 2.

9. Science Development Fund under the President of the Republic of Azerbaijan. Available at: http://www.sdf.gov.az/az//generic/ menu/Detail/100/menu (accessed 05 September 2020).

10. GLOBAL INNOVATION INDEX (2020), p. 221. URL: https://www.globalinnovationindex.org (accessed 05 September 2020). 


\section{РОЛЬ НАУКОВО-ТЕХНІЧНИХ ІННОВАЦІЙ У МОДЕРНІЗАЦІЇ СЕРЕДОВИЩА ЕКОНОМІКИ}

Анотація. Мета дослідження полягає у вивченні механізмів модернізації економіки та її впливу на економічну конкуренцію та розвиток, а також у визначенні внеску інноваційних досліджень у сфері науки та техніки в економічний розвиток Азербайджану. Проаналізувавши перспективи розвитку інноваційних досліджень у сфері науки та техніки, запропоновані заходи, яких слід вжити. Визначення ролі науково-технічних інновацій у модернізації економіки шляхом аналізу зарубіжного досвіду вимагає додаткового вивчення. Представлені матеріали та отримані результати можуть бути використані при розробці комплексних та систематизованих заходів, концептуальних підходів до вирішення проблем побудови сучасної інноваційно-орієнтованої економіки. Ми можемо стверджувати, що у сучасному взаємопов'язаному світі, знання, інформація та комунікація - це ключі до влади та процвітання, і те як потенціал кадрових ресурсів країн, що розвиваються, використовує їх, може мати значний вплив на формування суспільства в цілому. У статті досліджується міжнародний досвід розробки та застосування нових ідей, методів, продуктів тощо, що забезпечить економічні та соціальні вигоди для змін та оновлення продукції, послуг та методів виробництва, що базуються на новітніх науково-технічних досягненнях, для демонстрації сталої економічної діяльності в конкурентному середовищі, також представлені успішні практики. Обмеження фізичних можливостей людини були подолані завдяки технологічним розробкам, що докорінно змінило виробничий процес. Кількість товарів збільшувалася та урізноманітнювалася, у той час, як фабрично виробництво прискорювалося та зазнавало спрощень. В результаті, такі умови призвели до зменшення собівартості продукції. Світ та країни, що змінилися після промислової революції, зазнали впливу цих тенденцій, через що прискорилися перегони за місце у Новому світовому економічному порядку. Інформаційна ера, про народження якої проголошується знанням, має величезний вплив на життя суспільства, а також на економічні системи. Телекомунікації стали одним з основних каналів базової структури інформаційного суспільства і не лише вплинули на нього, але і призвели до абсолютно нової епохи економічної інформації та комунікації через те, як вона розширює функціонування інституцій. Подальша диверсифікація каналів зв'язку чітко залежить від здатності продукувати, обробляти інформацію та розширювати сфери ії використання.

Ключові слова: інновації, науково-технічний прогрес, економічний розвиток, інноваційний розвиток, технологічні зміни.

\section{РОЛЬ НАУЧНО-ТЕХНИЧЕСКИХ ИННОВАЦИЙ В МОДЕРНИЗАЦИИ СРЕДЫ ЭКОНОМИКИ}

Аннотация. Цель исследования заключается в изучении механизмов модернизации экономики и ее влияния на экономическую конкуренцию и развитие, а также в определении вклада инновационных исследований в области науки и техники в экономическое развитие Азербайджана. Проанализировав перспективы развития инновационных исследований в области науки и техники, предложены меры, которые следует принять. Определены роли научно-технических инноваций в модернизации экономики путем анализа зарубежного опыта. В статье исследуется международный опыт разработки и применения новых идей, методов, продуктов для обеспечения экономической и социальной выгоды, а также для изменений и обновления продукции, услуг и методов производства, основанных на новейших научно-технических достижениях, для демонстрации постоянной экономической деятельности в конкурентной среде, также представлены успешные практики.

Ключевые слова: инновации, научно-техническое развитие, экономическое развитие, инновационное развитие, технологические изменения. 